\title{
Efficiency of mesenchymal stem cell therapy in ulcerative colitis as assessed by the morphology of colon mucosa
}

\author{
Galina V. Fedotovskikh, Galija M. Shaymardanova, Manarbek B. Askarov, Maiya S. Zhumabayeva, Gulmira S. Dosataeva, \\ Aigerim K. Smagulova, Sapargul Marat, Tatyana G. Ezhelenko
}

National Scientific Medical Center, Nur-Sultan (Astana), Kazakhstan

Prof. Galina V. Fedotovskikh, MD, National Scientific

Medical Center, Abylaikhan Avenue 42, 010000, Nur-Sultan

(Astana), Kazakhstan
Phone: +7 (707) 2223256

E-mail: gvf_fedotovskikh@mail.ru

Citation: Fedotovskikh GV, Shaymardanova GM, Askarov MB et al. Efficiency of mesenchymal stem cell therapy in ulcerative colitis as assessed by the morphology of colon mucosa. Cell Ther Transplant 2019; 8(2): 58-62.

\section{Summary}

Usage of bone marrow mesenchymal stromal cells (MSCs) in human inflammatory bowel disease has proven its feasibility in clinical studies. The purpose of this work was to study morpho-functional state of large intestine mucosa (LIM) at the term of 10 months after a single infusion of cultured in vitro expanded mesenchymal bone marrow cells (MSC) added to standard therapy of patients with ulcerative colitis (UC).

\section{Materials and methods}

Initial group of the patients with UC included 18 subjects. Of those, nine patients received standard drug therapy (control group), six subjects underwent similar therapy supplied by a single transplantation of autologous MSCs (the study group). Clinical and functional state of the patients was assessed by indices, according to Truelove and Wiits, Mayo and Rakhmilevich. Routine light microscopy, as well as electron microscopic studies were performed for 320 large intestinal mucosa (LIM) biopsies. Specific histological and immunohistochemical examination was carried out in 64 samples. Histological signs of inflammatory activity were evaluated in points according to K.Geboes et al. (2000). Immunohistochemistry studies included expression of CD4, CD68, CD31, CD34, CD8, lgG, and Ki-67 markers. The electron microscopic technique was used as generally accepted. Semi-thin sections were stained by C. Humphrey and F. Pittman (1974). Ultrathin sections were observed and captured using a Libra 120 electron microscope.

\section{Results}

A single transplantation of autologous cultured bone marrow MSCs, in addition to standard therapy of patients with ulcerative colitis has generally improved clinical and laboratory signs of the disease as examined 10 months after treatment, when compared with initial clinical state and the control group. Upon morphological study of LIM in the study and control groups, erosive and ulcerative defects did persist or were slightly decreased. Indicators of positive dynamics in the LIM structure have manifested mainly in the patients of study group, as a decreased inflammatory response and restoration of intestinal crypts ("epithelial niche"), with increased number of goblet cells and decreased permeability of intestinal cover epithelium.

\section{Conclusion}

Single transplantation of autologous cultured bone marrow MSC could be implemented into the standard therapy of patients with ulcerative colitis, providing a positive effect upon morpho-functional state of LIM, thus promoting reduction of inflammatory response, recovery of crypts and cover epithelium.

\section{Keywords}

Ulcerative colitis, autologous bone marrow, mesenchymal cells, transplantation, intestinal crypts, morphology. 


\section{Introduction}

Modern therapy of inflammatory bowel disease takes into account the complex multifactorial pathogenetic mechanisms of development of this pathology $(1,2)$. In view of the immunocorrective and immunosuppressive properties of mesenchymal stem cells, it is important to study the effectiveness of cellular therapy for patients with ulcerative colitis (UC). Immune component of pathogenesis in these immunological disorders is of sufficient importance. The inclusion of mesenchymal stromal cell transplantation in anticytokine and immunosuppressive therapy in patients with ulcerative colitis and Crohn's disease contributed to the positive dynamics of the clinical remission of these diseases [3]. However, morphological changes in large intestine mucosa (LIM) following cell therapy are still poorly understood from the standpoint of the "stem cell niche" and the mechanisms of participation of mesenchymal stem cells (MSCs) in the regulation of regenerative processes. Histological assessment of the complete remission of UC after conventional therapy considered a "golden standard for the treatment of inflammatory bowel disease" provides controversial results, due to severe destructive ulcers and reparative sclerotic changes of the colon mucosa (CM) in these diseases [4].

The purpose of our study was to evaluate the morpho-functional state of the colon mucosa in patients with ulcerative colitis after a single transplantation of autologous cultured mesenchymal bone marrow cells (MSC) against the background of standard therapy.

\section{Patients and methods}

Patients with ulcerative colitis were divided into 3 groups undergoing clinical, laboratory and morphological studies. The initial group of patients with UC before treatment included 18 subjects. Nine patients of them, received standard anti-inflammatory therapy (control group) which included 5-aminosalicylic acid (mesalazine), azathiopril, prednisone. Nine patients were treated with standard therapy supplemented by single MSC transplantation (main group) with a follow-up terms of about 10 months. Mesenchymal stem cells from bone marrow were cultured in DMEM culture medium for 14-21 days. Amounts and viability of in vitro cultured mesenchymal cells were evaluated by light microscopy, assessing activity of proliferation-associated Ki-67 antigen, production of specific biologically active substances. Transplantation of autologous mesenchymal bone marrow cells was performed once at a dose of 120-200 million cells in $200 \mathrm{ml}$ of saline infused intravenously at a rate of $50 \mathrm{~mL} / \mathrm{h}$ for 2.5 hours. Clinical and functional state of the patients (age from 24 to 57 years, men 11 and 7 women) with UC in the course of treatment was assessed according to the modified classifications by Truelove and Witts with updated recommendations G. Adler [5], Mayo and Rakhmilevich indices [6], extraintestinal manifestations, hemoglobin level, ESR, CRP and fecal calprotectin. 64 samples light-optical (semi-thin sections) and 320 microscopic examination of biopsy material taken endoscopically from different parts of the large intestine were subjected to histological and immunohistochemical studies. Histological sections of CM were stained with hematoxylin and eosin. Histological evaluation of the activity of inflammatory bowel disease was carried out semiquantitavely by K. Geboes et al. [7]. At the same time, structural changes, the density of inflammatory infiltration and the defects of the CM mucosa were assessed from 0 to 3 points. Immunohistochemical studies included detection of CD4, CD68, CD31, CD34, CD8, lgG, Ki-67 expression. For electron microscopy, the biopsy samples were fixed in in a $2.5 \%$ solution of glutaraldehyde with postfixation in $1 \%$ $\mathrm{OsO}_{4}$ and then processed according to the standard technique [8]. Semi-thin and ultra-thin sections were obtained in a Leica EM UC 7 ultramicrotome (Austria). Semi-thin sections, which allow high-resolution light microscopy, were stained with Methylene Blue, Azur 2, and basic fuchsin dye, according to C. Humphrey and F. Pittman [9]. Ultrathin sections were contrasted with uranyl acetate and lead citrate according to Reynolds. Ultrathin sections were observed and captured using a Libra 120 electron microscope (K. Zeiss, Germany).

\section{Results}

Ten months after the beginning of treatment, the entire clinical and laboratory symptomatics of the patients from MCS-treated group improved or stabilized as compared to the initial condition, remaining unchanged or more severe in the control group. Significant differences in the dynamics of hemoglobin, C-reactive protein and fecal calprotein in patients of the main and control groups were not observed. Positive dynamics of normalization of the ESR level in patients of MSC-treated group were noted. In 4 patients of the main group (44.5\%), normalization of the ESR level was noted, in 3 of the studied (33.3\%) ESR remained at the same level, in 2 patients $(22.2 \%)$ there was an increase in the level of ESR. In the control group of patients receiving only standard therapy in 9 patients (100\%), the level of ESR did not change, including in patients with elevated ESR. Thus, in the main group compared with the control group, there was a positive trend in the normalization of ESR.

Meanwhile, periods of exacerbation were noted in 3 of 9 patients in the control group. The index of inflammatory activity of ulcerative colitis according to Rakhmilevich in the main group decreased from 6-9 to 4-5 points remained unchanged in the control group, and even being increased in one patient. Mayo index in the main group also slightly decreased from 7 to 5-6 points, but remained unchanged or increased in the control group. According to Truelove and Wiits scale, the degree of inflammatory activity remained unchanged in both groups, which may be explained by more generalized characteristics of this classification. When evaluating histological and immunohistochemical changes of large intestinal mucosa (LIM) in patients of the main and control groups compared with patients of the initial group, a decrease in T-lymphocytic inflammatory response was observed from severe and moderate to moderate and weak (from 2-3 to 1-2 points) with a decrease in the population of CD8+ lymphocytes. The density of the inflammatory infiltrate decreased from 2 to 3 points (Fig. 1, a). Erosive and ulcerative defects of CM (2-3 points) remained at similar level, or changed slightly. However, the number, length of crypts, number of goblet cells in epithelium and crypts were increased, flattening of 
the epithelium was decreased (from 2 to 1 point) and damage to the crypts (1-2 to $0-1$ points) was also diminished. Interepithelial neutrophilic infiltration with decreased. Eosinophilic infiltration of the lamina propria of the mucous membrane was absent. Indicators of the positive dynamics of improving the pathological characteristics of CM in the main group of patients were observed in 5 of 6 patients, in the control in 2 of 9 patients.

\section{Discussion}

Electron microscopic data revealed possible mechanisms of the positive effect of the secretion of mesenchymal stem cells on the immunocompetent, microcirculatory, neuro-
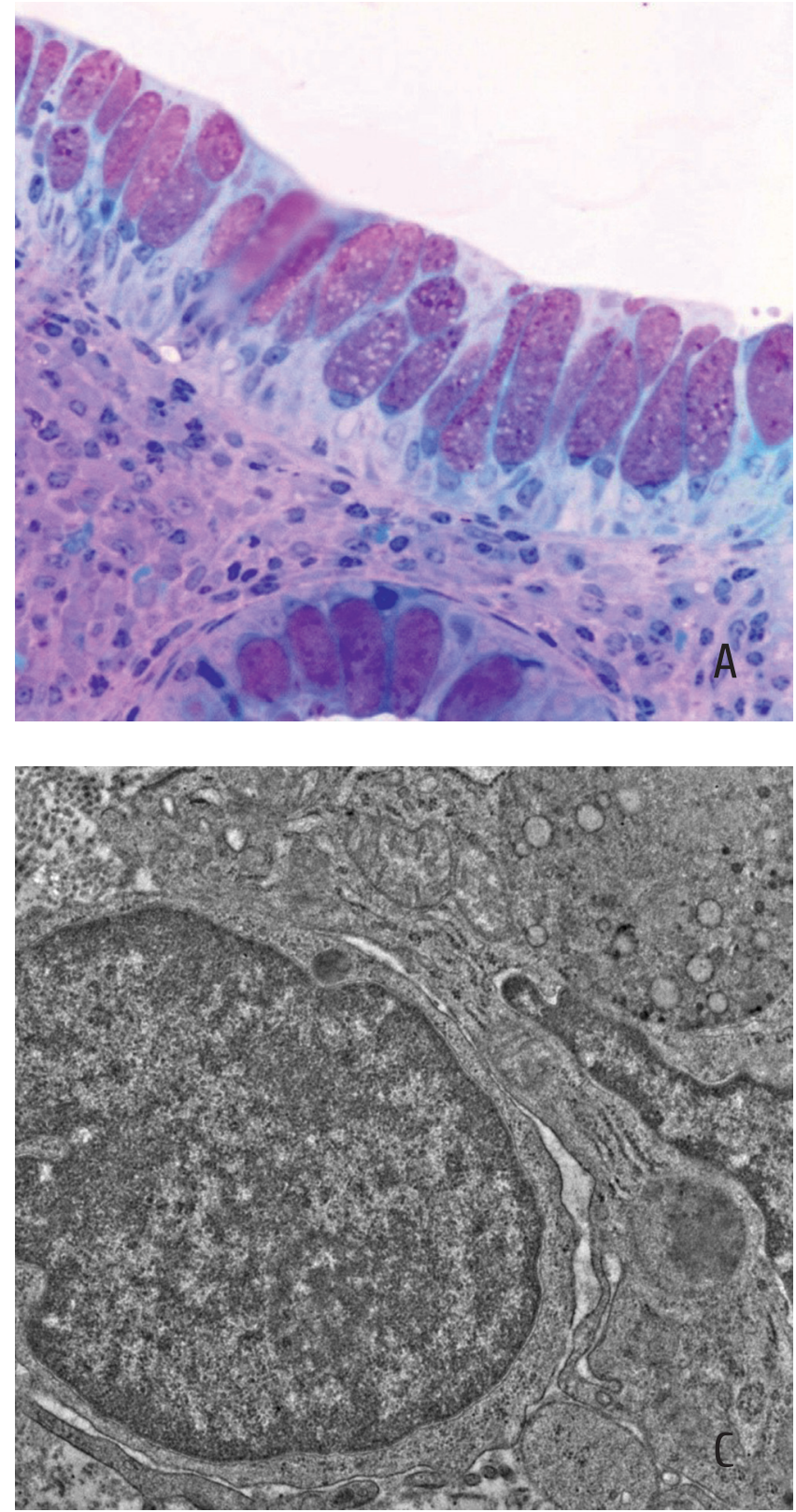

trophic systems, cellular and non-cellular components of the stroma of the mucous membrane of the large intestine and restoration of the epithelium. Numerous intimate contacts and small exosomes between lymphocytes, plasma cells and macrophages with high phagocytic and secretory activity were noted electronically (Fig. 1, b). Macrophages are given a key role in the presentation of the antigen and the realization of the effect of regeneration with the participation of various populations of lymphoid cells [10]. It is quite possible that the immunomodulating function of macrophages was also carried out with the help of telocytes, the long processes which were everywhere located between the cells of the inflammatory infiltrate (Fig. 1, c). First described as a new type of interstitial cells, telocytes are presumably involved in the
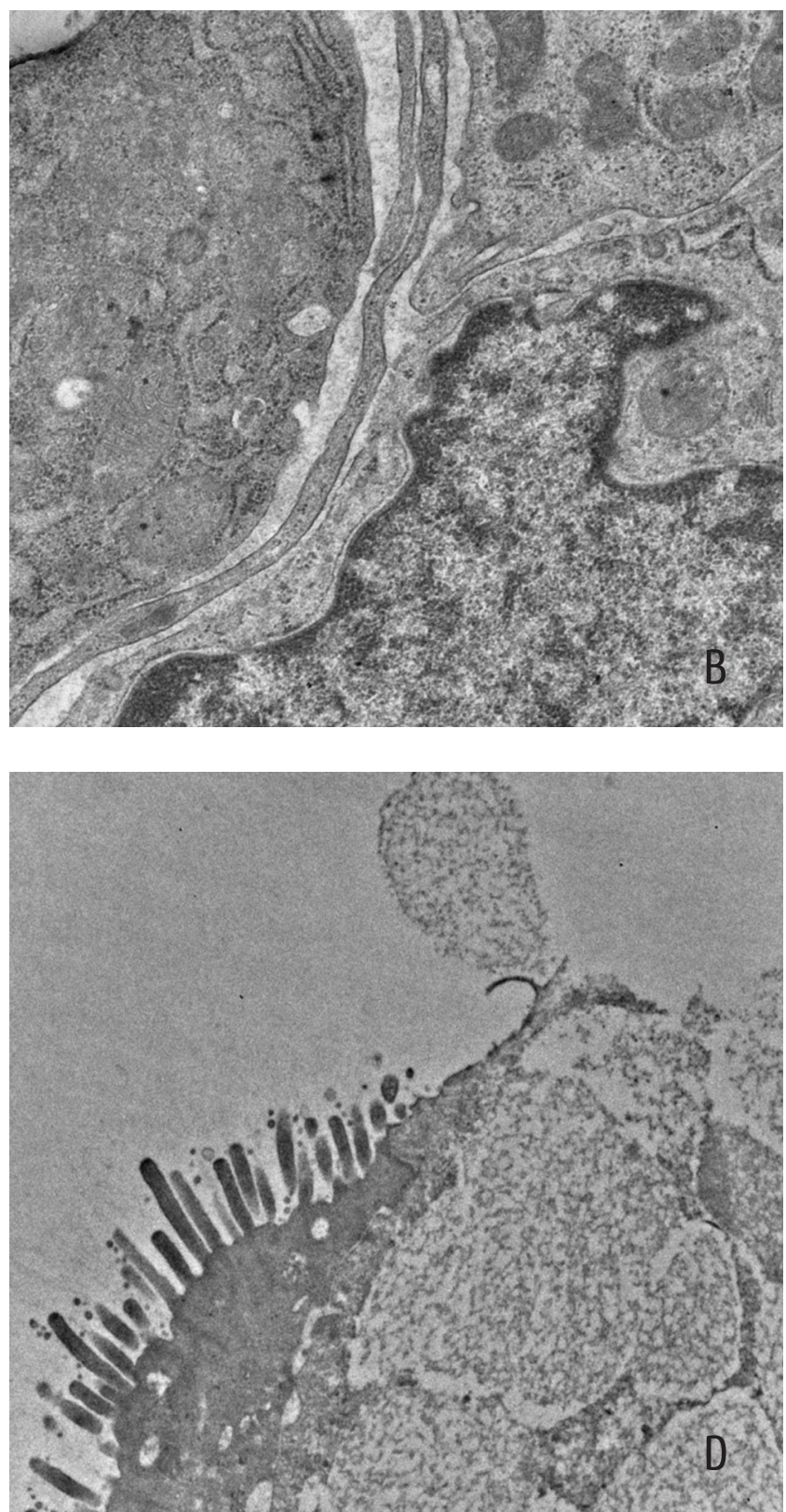

Figure 1. Morphology of large intestinal mucosa after 6 months of single MSCs transplantation with standard therapy

(a) Reduction in the density of lympho-plasmacytic inflammatory infiltrate increase in the number of goblet cells in the integumentary epithelium and crypts section. Semi-thin section. Staining with Methylene Blue, Azure-2 and basic fuchsin. x400.

(b) Tight intercellular contact between the lymphocyte and the macrophage. Electron diffraction technique.

(c) Telocyte between the cells of inflammatory infiltrate. Electron diffraction technique.

(d) Cylindrical cell with microvilli, and a goblet cell with granules of mucus. Electron diffraction technique. 
regeneration of tissues, the formation of stem cell niches and intercellular communication through the secretion of extracellular vesicles and nanocontacts [11]. A necessary requirement for assessing the number and condition of these cells is the visualization of their double immunohistochemical staining. Although the immunohistochemical indicators of the level of angiogenesis (CD 34+ cells) were as high as before the treatment, the blood capillaries were characterized by an increased "working" area of endothelium, pronounced vesicle formation and numerous outgrowth of the luminal and basal surface. Amyelinic terminal nerve endings were numerous and contained a large number of small axons. On semi-thin sections, we observed a decrease in the degree of fibrosis of the connective tissue, due to fibroclasia of collagen fibrils. The proliferative activity of the epithelium at the neck of crypts was high, as proven by the Ki-67 antigen expression. The proliferating cells were characterized by a high degree of differentiation into goblet cells, which indicates the restoration of the secretory function of the integumentary epithelium. Cylindrical cells located on the basement membrane had different degrees of differentiation. Less differentiated cells had the appearance of vacuolation cells with poorly developed microvilli. Typical cylindrical cells had well-developed microvilli and tight intercellular contacts between long cytoplasmic processes (Fig. 1, d). Single intercellular contacts such as desmosomes in the proliferating epithelium indicated the differentiation of stem cells in the direction of the squamous epithelium, as it was phylogenetically more ancient and stable. Multivesicular endosomes were related to secretory exosomes involved in the regulation of anti-inflammatory processes [12]. Destruction of the granular endoplasmic reticulum canaliculi, and the decrease in the density of secretory granules were noted in the cytoplasm of serotonin-containing cells. A decrease in the functional activity of serotonin-containing cells is characteristic of the stage of remission of ulcerative colitis [13].

\section{Conclusion}

Inclusion of a single autologous bone marrow MSC transplant into the standard therapy of patients with ulcerative colitis 10 months after treatment generally improved the clinical and laboratory picture of the disease, as compared with the initial state and the control group. In morphological study of LIM in patients of the main and control groups, erosive and ulcerative defects persisted or slightly decreased. Indicators of positive dynamics of improving the pathological characteristics of LIM manifested mainly in patients of the MSC-treated. Group, as a decrease in local inflammatory response and restoration of crypts ("epithelial niche") with increased number of goblet cells and a decrease in permeability of the cover epithelium. Thus, a single transplantation of autologous mesenchymal cultured bone marrow cells accompanied by standard therapy had a positive effect on the morpho-functional state of LIM in UC patients. As a part of the ongoing scientific and technical program, multiple MSC transplantation will be studied in order to achieve a more efficient histological LIM recovery in patients with ulcerative colitis.

\section{Conflict of interest}

None declared.

\section{Acknowledgement}

The work was carried out within the framework of the scientific and technical program "Transplantation of stem (mesenchymal) cells in regenerative medicine” 013 (2017-2019).

\section{References}

1. Soler D, Chapman T, Yang LL, Wyant T, Egan R, Fedyk ER. The binding specificity and selective antagonism of vedolizumab, an anti-alpha4beta7 integrin therapeutic antibody in development for inflammatory bowel diseases. J Pharmacol Exp Ther. 2009;330(3):864-875.

2. Farre R, Vicario M. Abnormal barrier function in gastrointestinal disorders, Handbook Exp Pharmacol. 2017:239:193-217.doi:10.1007/164_2016_107.

3. Knyazev OV, Fadeeva NA, Kagramanova AV, Lishchinskaya AA et al. Frequency of relapses in patients with ulcerative colitis and Crohn's disease, receiving cell therapy - 5 years of observation (Abstract). Materials of the III National Congress on Regenerative Medicine. Genes and Cells. 2017; $12(3)$.

4. Villanacci V, Antonelli E, Geboes K, Casella G, Bassotti G. Histological healing in inflammatory bowel disease: a still unfulfilled promise. World J Gastroenterol. 2013; 19(7): 968978.

5. Adler G. Crohn's disease and ulcerative colitis. Moscow: Geotar MED, 2001 (In Russian).

6. Annese V, Daperno M, Rutter MD, Amiot A, Bossuyt P, East J, Ferrante M, Götz M, Katsanos KH, Kießlich R, Ordás I, Repici A, Rosa B, Sebastian S, Kucharzik T, Eliakim R; European Crohn's and Colitis Organisation. European evidence based consensus for endoscopy in inflammatory bowel disease. J Crohns Colitis. 2013; 7(12):982-1018.

7. Geboes K, Riddell R, Ost A, Jensfelt B, Persson T, Löfberg R. A reproducible grading scale for histological assessment of inflammation in ulcerative colitis. Gut. 2000;47(3):404-409.

8. Glauert A. Fixation,dehydration and embedding of biological specimens. In: Practical Methods in Electron Microscopy ( Ed. By Glauert AM). North-Holland : American Elsevier.1975.

9. Humphrey C, Pittman F. A simple methylene blue-azure II-basic fuchsin stain for epoxy-embedded tissue sections. Stain Technol. 1974;49(1):9-14.

10. Murrey PJ, Wynn TA. Protective and pathogenic functions of macrophage subsets. Nature Rev Immunol. 2011; 11(11): 723-737. 
11. Popescu LM, Nicolescu MI. Telocytes and stem cells. (Inos Santos Goldenberg RC, de Carvalho ACC, eds). Resident stem cells and regenerative therapy. MA: Academic Press. 2013: 205-231.

12. van Niel G, Raposo G, Candalh C, Boussac M, Hershberg R, Cerf-Bensussan N, Heyman M. Intestinal epithelial cells secrete exosome-like vesicles. Gastroenterology. 2001;121(2):337-349.
13. Rybakova MG, Botina V, Solovyeva OI. Immunomorphological characteristic of the colon mucosal cells and endocrine structures in the patients with chronic ulcerous colitis. Arch Patol. 2005; 67(2):30-33 (In Russian).

\section{Эффективность клеточной терапии язвенного колита по данным морфологии слизистой оболочки толстой кишки}

Галина В. Федотовских, Галия М. Шаймарданова, Манарбек Б. Аскаров, Майя С. Жумабаева, Гульмира С. Досатаева, Айгерим К. Смагулова, Сапаргуль Марат, Татьяна Г. Ежеленко

АО «Национальный научный медицинский центр», г. Нур-Султан (Астана), Казахстан

\section{Резюме}

Применение мезенхимных стволовых клеток костного мозга (МСК) при воспалительных заболеваниях кишечника показало свою выполнимость в клинических исследованиях. Целью настоящей работы было исследование морфо-функционального состояния слизистой толстого кишечника в срок 10 мес. после единичной инфузии культивированных in vitro и размноженных МСК в дополнение к стандартной терапии больных с язвенным колитом (ЯК).

\section{Материалы и методы}

Исходная группа пациентов с ЯК включала 18 человек. Девять из них получали стандартную терапию (контрольная группа), а шесть человек проходили аналогичное лечение с добавлением разовой трансплантацией аутологичных МСК (экспериментальная группа). Клиническое и функциональное состояние пациентов оценивали по индексам Truelove и Wiits, а также Мауо и Rakhmilevich. Рутинная световая микроскопия, а также электронно-микроскопические (ЭМ) исследования проводили для 320 биоптатов слизистой толстого кишечника (СТК). Специфическое гистологическое и иммуногистохимическое обследование выполнено в 64 образцах. Гистологические признаки воспалительной активности оценивали в баллах по K.Geboes et al. Иммуногистохимические исследования включали анализ экспрессии маркеров CD4, CD68, CD31, CD34, CD8, $\mathrm{IgG}$ и $\mathrm{Ki}-67$. ЭМ проводили по общепринятой методике. Полутонкие срезы окрашивали по Humphrey и Pittman. Ультратонкие срезы изучали и локализовали с помощью электронного микроскопа Libra 120.

\section{Результаты}

Разовая трансплантация аутологичных культивированных МСК костного мозга в добавление к стандартной терапии больных с ЯК, в целом, улучшали клинические и лабораторные симптомы заболевания при исследовании через 10 мес. после лечения при сравнении с исходным клиническим статусом и контрольной группой. При морфологическом исследовании СТК в обеих группах была отмечена персистенция или некоторое уменьшение эрозивных и язвенных дефектов. Показатели позитивной динамики структуры СТК проявлялись, главным образом, у пациентов экспериментальной группы в виде снижения воспалительной реакции и восстановления кишечных крипт (“эпителиальной ниши”), c увеличением числа goblet-клеток и сниженной проницаемостью кишечного покровного эпителия.

\section{Заключение}

Разовая трансплантация аутологичных культивированных МСК костного мозга может быть внедрена в стандартную терапию пациентов с ЯК, что оказывает позитивный эффект на морфофунциональное состояние СТК, тем самым способствуя снижению воспалительной реакции, восстановлению крипт и покровного эпителия.

\section{Ключевые слова}

Язвенный колит, аутологичная трансплантация костного мозга, мезенхимные клетки, трансплантация, кишечные крипты, морфология. 